\title{
Bacterial Diversity in Biological Filtration System for the Simultaneous Removal of Arsenic, Iron and Manganese from Groundwater
}

\author{
Rajan THAPA CHHETRI*, Ichiro SUZUKI* **, Takuya FUJITA*, Minoru TAKEDA*, \\ Jun-ichi KOIZUMI*, Yoko FUJIKAWA***, Atushi MINAMI****, Tatsuhide \\ HAMASAKI $* * * *$, Masataka SUGAHARA $* * * *$ \\ *Department of Chemical and Energy Engineering, Graduate School of Engineering, \\ Yokohama National University, 79-5 Tokiwa-dai, Hodogaya, Yokohama, Kanagawa \\ 240-8501, Japan \\ **Center for Risk Management and Safety Sciences, Yokohama National University, 79-5 \\ Tokiwa-dai, Hodogaya, Yokohama, Kanagawa 240-8501, Japan \\ ***Research Reactor Institute, Kyoto University, 2 Asashiro-Nishi, Kumatori-cho, Sennan-gun, \\ Osaka 590-0494, Japan \\ ****Department of Human Life and Environment, Faculty of Human Environment, Osaka \\ Sangyo University, 3-1-1 Nakagaito, Daito, Osaka 574-8530, Japan.
}

\begin{abstract}
Bacterial diversity of the microbial consortia in a biological filtration pilot plant for the simultaneous removal of arsenic (As), iron (Fe) and manganese $(\mathrm{Mn})$ from groundwater was analyzed. PCR-based denaturing gradient gel electrophoresis (DGGE) of bacterial 16S ribosomal RNA (rRNA) genes represented at least 6 dominant signals and many weak signals. Phylogenetic analysis using the nucleotide sequences of the 16S rRNA gene clone library constructed from the pilot plant sample showed the presence of the bacteria closely related to Gallionella and Leptothrix, which are supposed to be involved in the production of Fe and $\mathrm{Mn}$ oxides utilized for adsorbents of As in this system. On the other hand, aoxB gene was not detected, suggesting that arsenite-oxidizing bacterium would not be involved in the As removal of the pilot plant. These results indicated that the simultaneous removal of As, Fe and Mn from groundwater was conducted by the physicochemical sorption of As by the biogenic Fe and $\mathrm{Mn}$ oxides produced by the bacteria closely related to Gallionella and Leptothrix included in the microbial consortia of the pilot plant.
\end{abstract}

Keywords: arsenic, biological filtration, Leptothrix

\section{INTRODUCTION}

Arsenic (As) contamination of the groundwater is a global problem affecting many countries. Because an increase of As concentration in the drinking water is associated with numerous health hazards, various treatment procedures are applied to reduce As level below the World Health Organization (WHO) guideline value of $10 \mu \mathrm{g} / \mathrm{L}$ (WHO, 1996). The conventional methods for the removal of As from groundwater, such as, precipitation-coagulation, ion-exchange, and reverse osmosis processes, generally require expensive devices or materials. Most of the As contaminations in groundwaters are permanent problems induced by natural mineral sources or mining activities, therefore, low-cost and easy-to-operate process for the removal of As should be required, especially for the developing economies. To solve this problem, alternative methods for As removal have been investigated using biological activities such as, biological incorporation, oxidation and volatilization (Čerňanský et al., 2007; Ike et al., 2008; Rahman and Hasegawa, 2011), or sorption of soluble As oxyanions onto biogenic

Address correspondence to Jun-ichi Koizumi, Department of Chemical and Energy Engineering, Yokohama National University, Email: jikoizmi@ynu.ac.jp

Received June 5, 2013, Accepted October 19, 2013. 
materials (Katsoyiannis and Zouboulis, 2004, 2006; Sahabi et al., 2009; Sari and Tuzen, 2009), which are less expensive than the conventional methods. Biological sorptive filtration for simultaneous removal of As, iron $(\mathrm{Fe})$ and manganese $(\mathrm{Mn})$ is one of the biological methods for As removal from groundwater, which utilizes biologically produced $\mathrm{Fe}$ and $\mathrm{Mn}$ oxides as the adsorbents for soluble As oxyanions. This method has an advantage over the other biological methods, since it is based on the biological filtration system for the removal of $\mathrm{Fe}$ and $\mathrm{Mn}$ from groundwater used in the drinking water treatment plants of many countries. In this system, a step of biological oxidation of $\mathrm{Fe}$ and $\mathrm{Mn}$ by the microorganisms in the reactor forms amorphous $\mathrm{Fe}$ and $\mathrm{Mn}$ oxide layers on the surface of filter media, and As species are subsequently removed from the groundwater by a combination of physicochemical adsorption and oxidation (Mohan and Pittman Jr., 2007; Hennebel et al., 2009; Sahabi et al., 2009). This method requires no chemical oxidant, and the sorbent materials are continuously produced in situ; therefore, the biological sorptive filtration is an economical, eco-friendly and easy-to-operate method for the treatment of groundwater containing As, Fe and $\mathrm{Mn}$. It is known that high concentration of As in groundwater is often associated with high concentrations of $\mathrm{Fe}$ and $\mathrm{Mn}$, thus the simultaneous removal of $\mathrm{As}, \mathrm{Fe}$ and $\mathrm{Mn}$ by biological filtration is applicable. A number of studies using biological filtration for the simultaneous removal of As and Fe (Katsoyiannis and Zouboulis, 2004; Casiot et al., 2006; Hassan et al., 2009; Pokhrel and Viraraghavan, 2009), or the simultaneous removal of As, Fe and Mn (Katsoyiannis and Zouboulis, 2006; Sugahara et al., 2008) exhibited effective removal of As from the water. However, composition and function of the microbial community in the biological filtration systems had not been studied in detail.

The biological filtration system has been considered to utilize the so-called "iron bacteria" for oxidation and deposition of $\mathrm{Fe}^{2+}$ and $\mathrm{Mn}^{2+}$ ions in groundwater (Mouchet, 1992; Pacini et al., 2005). Iron bacteria is a common name of the bacteria found in Fe and Mn-containing groundwater and freshwater environments, which oxidize Fe (Fe-oxidizing bacteria; FeOB), or both $\mathrm{Fe}$ and $\mathrm{Mn}$ ( $\mathrm{Fe}$ and Mn-oxidizing bacteria; $\mathrm{MnOB})$. These bacteria have been well known not only for their particular habitats but also for their unique structures, such as twisted stalks (Gallionella), and filamentous tubes called "sheath" (Leptothrix, Sphaerotilus, and Crenothrix) (van Veen et al., 1978; Ghiorse, 1984). These iron bacteria are assumed to deposit Fe and Mn oxides on their extracellular structures. However, because of the difficulty of their pure cultivation, their contribution on the removal of $\mathrm{Fe}$ and $\mathrm{Mn}$ from groundwater in the biological filtration system is poorly understood. Katsoyiannis and Zouboulis (2004) operated a biological filtration system for the simultaneous removal of As and Fe and showed the presence of Gallionella and Leptothrix in the biological filtration reactor (BFR) by microscopic analysis. This study used a raw groundwater containing Fe, which was spiked with As during the investigation. Battaglia-Brunet et al. (2006) investigated the simultaneous removal of As and Fe using the BFR inoculated with an enrichment culture of As-oxidizing microbial consortia and synthetic mine water, and isolated an As-oxidizing bacterium phylogenetically related to Leptothrix from the BFR. In addition, they studied the diversity of the bacterial consortia in the BFR using polymerase chain reaction (PCR)-based 16S ribosomal RNA (rRNA) gene sequence analysis, and showed the presence of 9 individual operational taxonomic units (OTUs) including the bacteria phylogenetically related to Gallionella. Casiot et al. (2006) 
operated the biological filtration system using Fe and As-containing groundwater, and isolated an As-oxidizing bacterium from the BFR. In addition, they analyzed the diversity of the bacterial consortia in the biofilm from the BFR by PCR-based terminal-restriction fragment length polymorphism (T-RFLP) of the 16S rRNA genes, and showed the presence of 14 OTUs. On the other hand, bacterial diversity in the BFR for the simultaneous removal of As, Fe and Mn was not reported yet. Previously, we studied the bacterial diversity in the biological filtration system for the removal of Fe and $\mathrm{Mn}$ from groundwater used in the drinking water treatment plant located at Joyo City, Kyoto, Japan, using the PCR-based denaturing gradient gel electrophoresis (DGGE) and clone library analyses of the bacterial 16S rRNA genes (Thapa Chhetri et al., 2013). The results showed the presence of FeOB such as Gallionella and Sideroxydans, and MnOB such as Hyphomicrobium in the BFR, which possibly contribute for the removal of $\mathrm{Fe}$ and $\mathrm{Mn}$ from groundwater. In this report, we studied bacterial diversity of the biological filtration plant for the simultaneous removal of As, Fe and Mn. A pilot plant for the biological treatment of groundwater containing As, Fe and Mn using a column reactor had been operated for 6 months (Sugahara et al., 2008; Fujikawa et al., 2010). During the operation, As, Fe and $\mathrm{Mn}$ in the raw groundwater were successfully removed. The aim of this study is to analyze the bacterial diversity in the pilot plant of biological filtration system for the simultaneous removal of As, Fe and Mn from groundwater, using PCR-based molecular biological techniques, such as, PCR-DGGE, clone library analysis, and real-time PCR. Furthermore, we compared the community structure of bacterial consortia on the pilot plant with that of the other biological filtration plant which we analyzed previously. This is the first study for the analysis of bacterial diversity in the biological filtration plant for the simultaneous removal of $\mathrm{As}, \mathrm{Fe}$ and $\mathrm{Mn}$, and it would be informative for researchers and engineers who are studying and developing the biological treatment system for the simultaneous removal of As, Fe and Mn.

\section{MATERIALS AND METHODS}

\section{Sampling site}

The microbial floc and raw groundwater samples were collected from the biological filtration pilot plant for the simultaneous removal of As, Fe and Mn, located at Muko City, Kyoto, Japan (Sugahara et al., 2008; Fujikawa et al., 2010). The system consists of aeration by dropping, and downflow filtration reactor $(\varnothing 100 \mathrm{~mm} \times 1,800 \mathrm{~mm}$ column $)$ with dual-media filter of polypropylene tubes $(5-8 \mathrm{~mm}$ in pore size, ca. 1,000 $\mathrm{mm}$ in height) and Mn-coated sands (ca. $200 \mathrm{~mm}$ in height). From May to November, 2006, this system was operated at the filtration rates of 150 to $600 \mathrm{~m} /$ day. The microbial floc sample in the filter bed of the reactor was collected from the backwashed water of the column reactor on September 21,2006 , and stored at $-80^{\circ} \mathrm{C}$. Raw groundwater sample was collected in polypropylene bottle, filtered through a $0.45 \mu \mathrm{m}$ membrane filter, and then stored at room temperature until analysis. The concentrations of $\mathrm{Fe}$ and $\mathrm{Mn}$ in the groundwater were determined by inductively coupled plasma atomic emission spectrometry (ICP-AES), while the concentration of total As was determined using hydride generation-atomic absorption spectrometry. The concentration of ammonium-nitrogen was determined by indophenol blue method (Solorzano, 1969). The biological filter media sample from Joyo biological filtration plant was collected as described previously (Thapa Chhetri et al., 2013). 


\section{DNA extraction}

Total DNA was extracted from $0.05 \mathrm{~g}$ (wet weight) of the microbial floc sample using FastDNA SPIN Kit for soil (MP Biochemicals, Solon, OH, USA) as described previously (Thapa Chhetri et al., 2013). Total DNA from Joyo biological filter media sample was also prepared as described (Thapa Chhetri et al., 2013).

\section{Polymerase chain reaction (PCR)}

Standard PCR procedure, and PCR procedure for the DGGE analysis with touchdown program, were carried out as described previously (Thapa Chhetri et al., 2013).

\section{Denaturing gradient gel electrophoresis}

To analyze the molecular diversity of bacterial consortia in the samples, about 190 base pairs (bp) of DNA fragments containing the variable region 3 of bacterial 16S rRNA genes were amplified. Parallel DGGE analysis was carried out using mini-DGGE system NB-1490 (Nihon Eido, Tokyo, Japan) as described previously (Thapa Chhetri et al., 2013). For the analysis, $12.5 \mu \mathrm{L}$ of PCR products were applied onto $8 \%$ (wt/vol) polyacrylamide gel with the denaturing gradients ranging from 30 to $60 \%$ denaturant, and electrophoresis was carried out in $1 \times \mathrm{TBE}$ buffer at $50 \mathrm{~V}, 60^{\circ} \mathrm{C}$ for $4.5 \mathrm{~h}$. The gel was visualized by SYBR Green I staining (Invitrogen, Carlsbad, CA, USA) using fluorescent image analyzer FLA-2000 (Fujifilm, Tokyo, Japan). A reference marker for DGGE analysis was prepared by mixing PCR-amplified 16S rRNA fragments of different Joyo clones obtained in the previous study (Thapa Chhetri et al., 2013). The determination of nucleotide sequence of the separated DNA fragment in the gel was performed as described previously (Thapa Chhetri et al., 2013).

\section{Clone library analysis}

To construct $16 \mathrm{~S}$ rRNA gene clone library from the sample, PCR amplification was carried out by the standard PCR procedure as described above using universal primers 63F (Marchesi et al., 1998) and 1392R (Lane et al., 1985). The resulted PCR product was introduced into pCR4-TOPO vector using TOPO TA Cloning Kit for Sequencing (Invitrogen) according to the manufacturer's protocol. Plasmid DNA harboring each 16S rRNA gene clone was prepared using E.Z.N.A. Plasmid Mini Kit I (Omega Bio-Tek, Norcross, GA, USA), and then subjected to sequence analysis. The determination and analysis of the nucleotide sequence of each plasmid clone was described previously (Thapa Chhetri et al., 2013).

\section{Nucleotide sequence accession numbers}

The nucleotide sequence data obtained in this study are deposited in the DNA Data Bank of Japan (DDBJ) database under accession numbers AB604792 to AB604838.

\section{Real-time PCR}

Real-time PCR was carried out to analyze the relative amount of the 16S rRNA genes of Leptothrix-related bacteria to that of the total bacteria in the sample as described previously (Thapa Chhetri et al., 2013).

\section{PCR detection of the genes encoding bacterial ammonia monooxygenase and arsenic oxidase}

The presence of the genes encoding ammonia monooxygenase subunit $\mathrm{A}(\mathrm{amoA})$ of 
ammonia-oxidizing bacteria (AOB) and ammonia-oxidizing archaea (AOA) in the total DNA sample was examined using PCR as described previously (Thapa Chhetri et al., 2013). For PCR detection of the gene encoding arsenite oxidase large subunit (aoxB) in the total DNA sample, primers aoxBM1-2F and aoxBM3-2R (Quéméneur et al., 2008) were used. PCR was carried out with the standard PCR condition as described above.

\section{RESULTS AND DISCUSSION}

Analysis of bacterial diversity in the biological filtration pilot plant by PCR-DGGE The biological filtration plant utilizes the microorganisms naturally present in raw groundwater. Therefore, the structure of microbial consortia in the plant would be affected by the characteristics of the influent groundwater. Basic characteristics of the raw groundwaters used in the pilot plant and Joyo biological filtration plant are listed in Table 1. The concentrations of $\mathrm{Fe}, \mathrm{Mn}, \mathrm{As}$ and ammonium ion $\left(\mathrm{NH}_{4}{ }^{+}\right)$in the raw groundwater of the pilot plant were higher than those of Joyo plant. To study the bacterial diversity in the biological filtration pilot plant for the simultaneous removal of As, Fe and Mn, microbial flocs accumulated in the BFR were collected. At that period, the concentrations of As, Fe and $\mathrm{Mn}$ in the influent raw groundwater were $22.5 \mu \mathrm{g} / \mathrm{L}$, $2.11 \mathrm{mg} / \mathrm{L}$ and $0.48 \mathrm{mg} / \mathrm{L}$, respectively, while those in the treated water were $5.5 \mu \mathrm{g} / \mathrm{L}$, $0.01 \mathrm{mg} / \mathrm{L}$ and $0.13 \mathrm{mg} / \mathrm{L}$, respectively. The concentration of As was successfully decreased under the WHO's guideline level. The concentration of $\mathrm{NH}_{4}{ }^{+}$in the raw groundwater was $0.76 \mathrm{mg} / \mathrm{L}$, which was not detected in the treated water. To depict the overview of bacterial diversity in the BFR of the pilot plant, the total DNA of the microbial consortia was extracted from the sample and applied for PCR-based DGGE analysis. Figure 1 shows that at least six strong signals and many weak signals of the amplified 16S rRNA gene fragments were observed. The patterns of PCR-amplified 16S rRNA genes separated by DGGE (DNA fingerprints) were compared between the samples from the pilot plant and Joyo biological filtration plant. However, no common signal was observed. In Joyo sample, one strong signal corresponded to the bacteria closely related to Gallionella, and the other three signals corresponded to the bacteria closely related to Nitrospira (Thapa Chhetri et al., 2013). Casiot et al. (2006) analyzed the diversity of bacterial consortia in the BFR using T-RFLP and showed that the dominant OTU was arsenite-oxidizing bacterium strain B2. The $16 \mathrm{~S}$ rRNA gene fragments observed in the pilot plant sample were excised from the gel and then applied for the determination of the nucleotide sequences. However, all these DNA fragments showed ambiguous nucleotide sequences, because of the contamination of multiple fragments which were probably due to the insufficient separation in the gel. 
Table 1 - Basic characteristics of the pilot plant and Joyo biological filtration plant.

\begin{tabular}{|c|c|c|}
\hline & Pilot plant $^{\mathrm{a}}$ & Joyo $^{b}$ \\
\hline \multicolumn{3}{|l|}{ Raw groundwater } \\
\hline Temperature $\left({ }^{\circ} \mathrm{C}\right)$ & 18.9 & 19.0 \\
\hline $\mathrm{pH}$ & 6.5 & 6.78 \\
\hline $\mathrm{Fe}(\mathrm{mg} / \mathrm{L})$ & 2.11 & 0.41 \\
\hline $\mathrm{Mn}(\mathrm{mg} / \mathrm{L})$ & 0.48 & 0.12 \\
\hline As $(\mu \mathrm{g} / \mathrm{L})$ & 22.5 & $-{ }^{\mathrm{d}}$ \\
\hline $\mathrm{NH}_{4}{ }^{+}-\mathrm{N}(\mathrm{mg} / \mathrm{L})$ & 0.76 & 0.11 \\
\hline $\mathrm{TOC}^{\mathrm{c}}(\mathrm{mg} / \mathrm{L})$ & 0.4 & $<0.5$ \\
\hline Hardness $\left(\mathrm{mg} / \mathrm{L}\right.$ as $\left.\mathrm{CaCO}_{3}\right)$ & 54.0 & 27.2 \\
\hline \multicolumn{3}{|l|}{ Biological filtration reactor } \\
\hline $\mathrm{DO}(\mathrm{mg} / \mathrm{L})$ & $3.5 \pm 0.9^{\mathrm{e}}$ & $5-7$ \\
\hline Filter media & $\begin{array}{l}\text { Polypropylene tubes, } \\
\text { Mn-coated sands }\end{array}$ & Anthracites, sands \\
\hline Filter surface area $\left(\mathrm{m}^{2}\right)$ & $7.85 \times 10^{-3}$ & $189\left(31.5 \mathrm{~m}^{2} \times 6\right.$ filters $)$ \\
\hline Filtration rate (m/day) & $150-600$ & 70 \\
\hline Backwash frequency & $1-2$ days & 14 days \\
\hline $\begin{array}{l}\text { a. On Oct. 5, } 2006 . \\
\text { b. Thapa Chhetri et al., } 2013 . \\
\text { c. Total organic carbon. } \\
\text { d. Not detected. } \\
\text { e. Sugahara et al., } 2008 .\end{array}$ & & \\
\hline
\end{tabular}

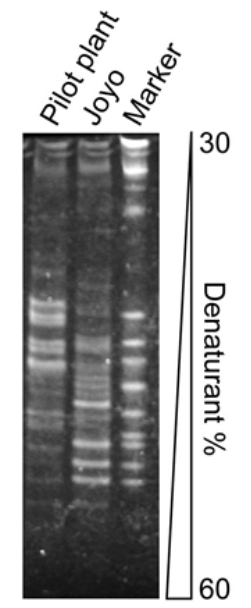

Fig. 1 - Comparison of the DNA fingerprints of PCR-amplified 16S rRNA genes from the pilot plant and Joyo biological filtration plant samples by parallel DGGE.

\section{Analysis of 16S rRNA gene clone library constructed from bacterial consortia in the pilot plant}

To study the bacterial diversity of the pilot plant in detail, 16S rRNA gene clone library was constructed. PCR-amplified 16S rRNA gene fragments were applied for the construction of the clone library, and 92 clones were isolated. These clones were then subjected to the determination of nucleotide sequence, and separated into 47 OTUs according to their nucleotide sequences. Nucleotide sequence of the first half of each cloned 16S rRNA gene fragment (corresponds to Escherichia coli 16S rRNA positions 64 to 784) was submitted to BLAST analysis to identify the closest known relative (Table 2). The dominant groups of the clones were affiliated with four subclasses of the 
Proteobacteria; Alphaproteobacteria (11 OTUs, 41\% of total clones), Betaproteobacteria (7 OTUs, 13\% of total clones), Gammaproteobacteria (11 OTUs, $13 \%$ of total clones), and Deltaproteobacteria (8 OTUs, $15 \%$ of total clones). The other clones were affiliated with Actinobacteria (5 OTUs, 9\% of total clones), Acidobacteria (4 OTUs, $8 \%$ of total clones), and Firmicutes (1 OTU, 1\% of total clones).

Table 2 - Similarities among 16S rDNA sequences of the clone library from the biological filtration pilot plant and the most similar database sequences.

\begin{tabular}{|c|c|c|c|c|}
\hline OTU name & Accession no. & $\begin{array}{l}\text { No. of } \\
\text { isolates }\end{array}$ & Closest relative $^{\mathrm{b}}$ [Accession no.] & Similarity $(\%)$ \\
\hline \multicolumn{5}{|c|}{ Alphaproteobacteria } \\
\hline M07A146 & $\mathrm{AB} 604837$ & 1 & Beijerinckia fluminensis LMG 2819 [EU401905] & 94.3 \\
\hline M07A071 & AB604819 & 1 & Bradyrhizobium sp. II-47 [AB531406] & 100.0 \\
\hline M07A072 & AB604820 & 3 & Bradyrhizobium sp. Wall28 [EF601950] & 99.4 \\
\hline M07A022 & AB604800 & 7 & Methylocystis sp. B3 [DQ496232] & 99.1 \\
\hline M07A144 & AB604836 & 1 & Nordella oligomobilis N21 [AF370880] & 96.0 \\
\hline M07A009 & AB604794 & 2 & Novosphingobium naphthalenivorans TUT562 [AB177883] & 96.1 \\
\hline M07A054 & AB604814 & 7 & Novosphingobium naphthalenivorans TUT562 [AB177883] & 96.2 \\
\hline M07A017 & AB604798 & 12 & Novosphingobium subterraneum F-4 [FJ527720] & 98.0 \\
\hline M07A121 & AB 604828 & 2 & Novosphingobium subterraneum F-4 [FJ527720] & 97.6 \\
\hline M07A034 & AB604804 & 1 & Rhodobacter capsulatus ATCC 11166 [DQ342320] & 97.4 \\
\hline M07A128 & $\mathrm{AB} 604833$ & 1 & Rhodobacter sp. ZH15 [FJ872532] & 94.4 \\
\hline \multicolumn{5}{|c|}{ Betaproteobacteria } \\
\hline M07A125 & AB604831 & 1 & Gallionella capsiferriformans ES-2 [DQ386262] & 95.2 \\
\hline M07A046 & AB604808 & 1 & Ideonella sp. 0-0013 [AB211233] & 96.2 \\
\hline M07A007 & AB604793 & 6 & Ideonella sp. B513 [AB049107] & 97.3 \\
\hline M07A053 & $\mathrm{AB} 604813$ & 1 & Methylibium fulvum Gsoil 328 [AB245357] & 99.0 \\
\hline M07A023 & AB604801 & 1 & Methylophilus sp. ECd5 [AY436794] & 95.4 \\
\hline M07A080 & AB604821 & 1 & Methylophilus sp. ECd5 [AY436794] & 96.8 \\
\hline M07A047 & AB604809 & 1 & Rhodoferax sp. IMCC 1723 [DQ664242] & 98.3 \\
\hline \multicolumn{5}{|c|}{ Gammaproteobacteria } \\
\hline M07A030 & AB604802 & 1 & Crenothrix polyspora clone $6[\mathrm{DQ} 295898]^{\mathrm{c}}$ & 94.8 \\
\hline M07A039 & AB604806 & 2 & Crenothrix polyspora clone 6 [DQ295898 $^{\mathrm{c}}$ & 94.8 \\
\hline M07A102 & AB604826 & 1 & Crenothrix polyspora clone 6 [DQ295898 $^{\mathrm{c}}$ & 93.4 \\
\hline M07A122 & AB604829 & 1 & Legionella lytica L2 [X97364] & 95.3 \\
\hline M07A088 & AB604823 & 1 & Legionella pneumophila Paris [CR628336] & 94.1 \\
\hline M07A052 & AB604812 & 1 & Lysobacter brunescens str. KCTC 12130 [AB161360] & 99.5 \\
\hline M07A148 & AB604838 & 1 & Lysobacter brunescens str. KCTC 12130 [AB161360] & 99.6 \\
\hline M07A069 & AB604818 & 1 & Methylobacter tundripaludum SV96 [AJ414655] & 96.8 \\
\hline M07A090 & AB604824 & 1 & Methylobacter tundripaludum SV96 [AJ414655] & 94.4 \\
\hline M07A015 & AB604797 & 1 & Methylomonas sp. LW16 [AF150796] & 97.6 \\
\hline M07A096 & AB604825 & 1 & Pseudomonas sp. 24 [FJ867623] $^{\mathrm{c}}$ & 89.2 \\
\hline \multicolumn{5}{|c|}{ Deltaproteobacteria } \\
\hline M07Ä041 & AB604807 & 1 & Anaeromyxobacter sp. IN2 [FJ939131] & 95.2 \\
\hline M07A060 & AB604817 & 2 & Anaeromyxobacter sp. K [CP001131] & 92.6 \\
\hline M07A051 & AB604811 & 2 & Bdellovibrio sp. MPA [AY294215] & 89.9 \\
\hline M07A049 & AB604810 & 4 & Geobacter chapelleii 172 [U41561] & 93.3 \\
\hline M07A010 & $\mathrm{AB} 604795$ & 2 & Geobacter argillaceus G12 [DQ145534] & 95.3 \\
\hline M07A082 & AB604822 & 1 & Geobacter argillaceus G12 [DQ145534] & 94.9 \\
\hline M07A055 & AB604815 & 1 & Geobacter psychrophilus P11 [AY653551] & 96.6 \\
\hline M07A031 & AB604803 & 1 & Haliangium tepidum SMP-10 [AB062751] & 85.7 \\
\hline \multicolumn{5}{|l|}{ Firmicutes } \\
\hline M07A124 & $\mathrm{AB} 604830$ & 1 & Staphylococcus epidermidis ATCC 12228 [AE015929] & 99.9 \\
\hline \multicolumn{5}{|c|}{ Actinobacteria } \\
\hline M07A059 & AB604816 & 2 & Actinobacterium YM22-133 [AB286031 $]^{\mathrm{c}}$ & 90.6 \\
\hline M07A126 & AB604832 & 1 & Actinobacterium YM22-133 [AB286031 $]^{\mathrm{c}}$ & 90.5 \\
\hline M07A140 & AB604834 & 2 & bacterium Ellin 5025 [AY234442] $^{\mathrm{c}}$ & 94.2 \\
\hline M07A142 & $\mathrm{AB} 604835$ & 2 & bacterium Ellin 5025 [AY234442] $^{\mathrm{c}}$ & 94.4 \\
\hline M07A014 & AB604796 & 1 & Sporichthya polymorpha DSM 46113 [X72377] & 94.3 \\
\hline \multicolumn{5}{|c|}{ Acidobacteria } \\
\hline M07A019 & AB604799 & 1 & Acidobacteria bacterium IGE-011 [GU187027] ${ }^{\mathrm{c}}$ & 89.8 \\
\hline M07A002 & AB604792 & 3 & Geothrix fermentans $\mathrm{H} 5$ [U41563] & 94.7 \\
\hline M07A035 & AB604805 & 1 & Geothrix fermentans H5 [U41563] & 96.5 \\
\hline M07A103 & AB604827 & 2 & Geothrix fermentans H5 [U41563] & 96.5 \\
\hline
\end{tabular}

a. Total 92 clones were isolated.

b. Based on BLAST analysis using the greengenes database.

c. Based on BLAST analysis using the DDBJ database. 
BLAST searches indicated that a number of OTUs showed higher sequence similarities (>95\%) to known FeOB and MnOB. The OTU M07A125 showed 95.2\% similarity to Gallionella capsiferriformans ES-2, which is a chemolithotrophic FeOB (Emerson and Moyer, 1997). The OTUs M07A007 and M07A046 showed $>96 \%$ similarities to Ideonella. The oxidation of Fe and Mn by Ideonella had not been reported, but it should be noted that these two OTUs also showed higher similarities to the Mn-depositing Burkholderiales bacterium JOSHI_001 isolated from the urban stream (Smith and Lewis, 2008), and arsenite-oxidizing bacterium Leptothrix sp. S1.1 isolated from the settling pond sediments of As and Fe-containing mine drainage water (Battaglia-Brunet et al., 2006). The nucleotide sequence similarities of the OTUs M07A007 and M07A046 to JOSHI 001 were $96.7 \%$ and $96.2 \%$, respectively, while those to Leptothrix sp. S1.1 were $96.9 \%$ and $95.1 \%$, respectively. The OTUs M07A030, M07A039 and M07A102 showed $>93 \%$ similarities to one of the sheathed iron bacteria Crenothrix polyspora (Stoecker et al., 2006), however, the Fe or Mn deposition activity of C. polyspora is still unknown (Emerson et al., 2010).

Phylogenetic relationships among all OTUs from the pilot plant for the simultaneous removal of $\mathrm{As}, \mathrm{Fe}$ and $\mathrm{Mn}, 32$ OTUs from Joyo biological filtration plant (Thapa Chhetri et al., 2013) and 16S rRNA gene sequences of the known relatives are shown in Fig. 2. Interestingly, the OTUs closely related to the genus Gallionella were present in the pilot plant and Joyo plant (M07A125 and Jy04A41), whereas the OTUs closely related to the other FeOB Sideroxydans were found in Joyo plant only. Sideroxydans spp. are microaerobic, chemolithotrophic bacteria which can utilize $\mathrm{Fe}^{2+}$ as an energy source the same as Gallionella, but they do not produce the twisted stalk (Emerson and Moyer, 1997; Emerson et al., 2010). As well as the pilot plant, Battaglia-Brunet et al. (2006) showed the presence of the 16S rRNA gene clones phylogenetically close to Gallionella in the bacterial consortia from the BFR for the simultaneous removal of As and Fe. Recently, Emerson et al. (2013) compared the genomes of G. capsiferriformans ES-2 and Sideroxydans lithotrophicus ES-1, and described that G. capsiferriformans ES-2 has more capacity to resist heavy metals than S. lithotrophicus ES-1.

The OTUs phylogenetically close to Leptothrix were obtained from the pilot plant (M07A007 and M07A046), but not from Joyo biological filtration plant. Among all the OTUs from Joyo and the pilot plants, these two OTUs and another four OTUs phylogenetically close to Methylibium (Jy04A04, Jy04A06, Jy04A46, and M07A053) contained the target sequence of a Leptothrix-specific probe PSP-6 (Siering and Ghiorse, 1997). Methylibium spp. are methylotrophic bacteria (Nakatsu et al., 2006), but their $\mathrm{Mn}^{2+}$ oxidation activity are unknown. The amounts of $16 \mathrm{~S}$ rRNA genes of the total bacteria and Leptothrix-related bacteria harboring the PSP-6 sequence in the DNA solution extracted from the microbial floc sample of the pilot plant were estimated using real-time PCR. The copy number of the 16S rRNA genes of the Leptothrix-related harboring the PSP- 6 sequence bacteria was $1.93 \times 10^{10}$ copies per one gram of the flocs, while that of total bacteria was $1.89 \times 10^{11}$ copies per one gram of the flocs; thus, the ratio was $10.2 \%$. Our previous study of Joyo sample indicated that the relative amount of the 16S rRNA gene copies of Leptothrix-related bacteria to those of the total bacteria in Joyo bacterial consortia was $12.5 \%$ (Thapa Chhetri et al., 2013); therefore, the ratios of the bacteria harboring PSP-6 sequence in the pilot plant and Joyo plant were quite similar. However, it is supposed that the proportion of the bacteria closely related to 
Leptothrix in the pilot plant would be larger than that in Joyo plant, because 7 isolates (7.6\% of total clones) were affiliated with the OTUs closely related to Leptothrix in the pilot plant clone library, whereas no isolate closely related to Leptothrix was obtained from Joyo clone library.

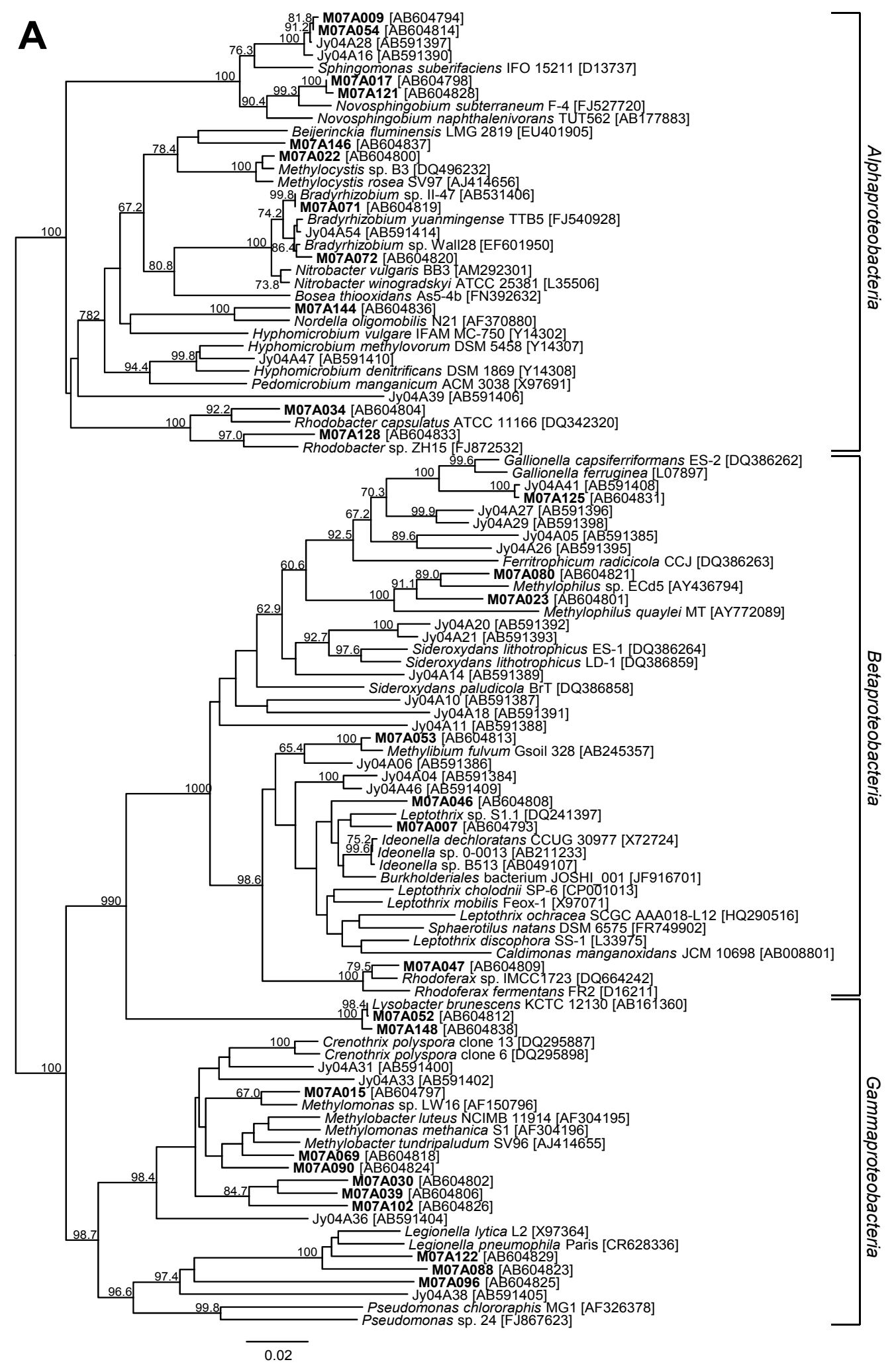




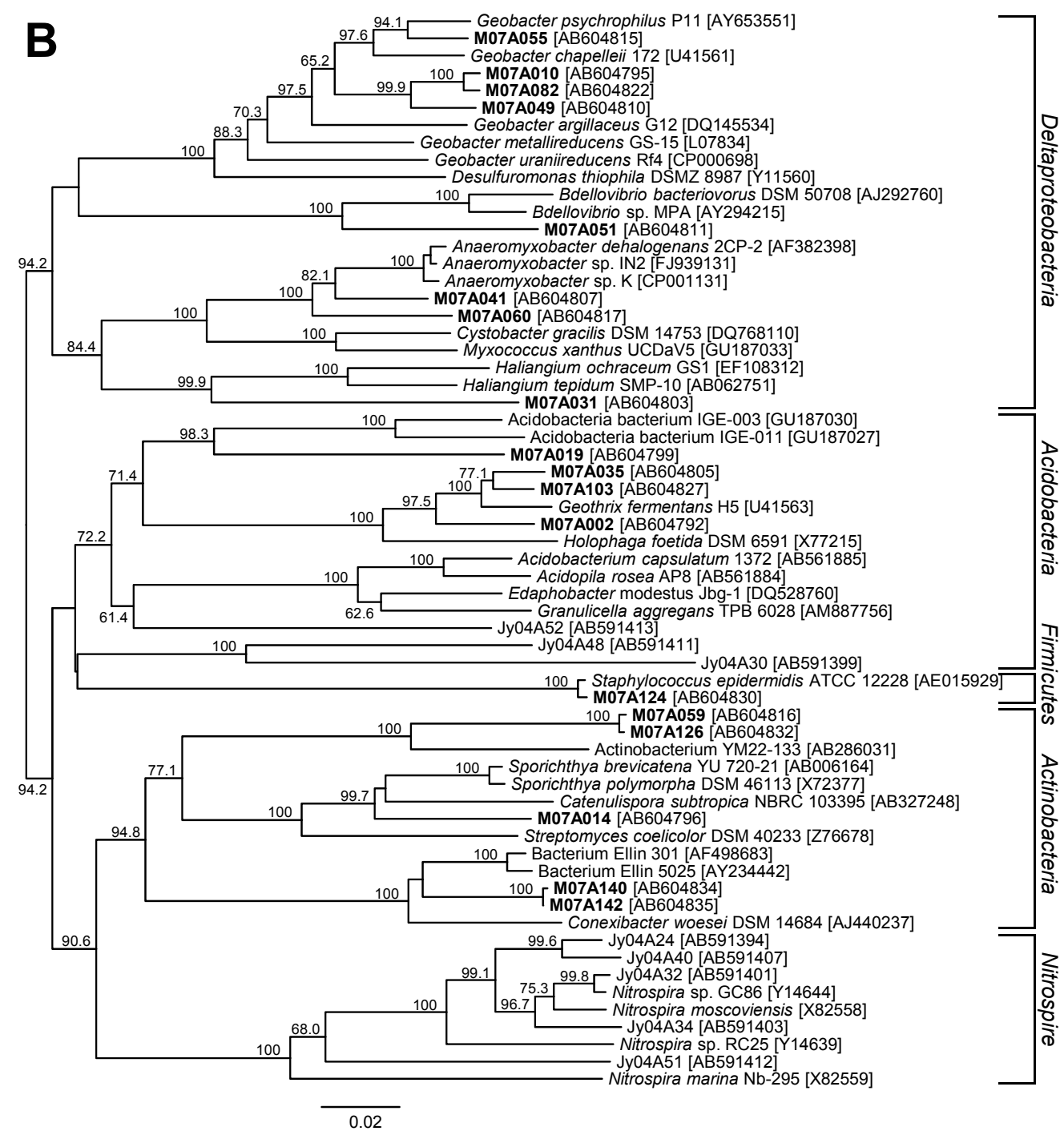

Fig. 2 - Phylogenetic relationships of bacterial 16S rRNA gene sequences obtained from the clone libraries of the biological filtration plants and relative bacteria. (A) Alpha, Beta, and Gamma-subclasses of Proteobacteria; (B) Deltaproteobacteria, Acidobacteria, Firmicutes, Actinobacteria, and Nitrospira. Bootstrap values of $>60 \%$ (obtained with 1,000 resamplings) are shown above or near the relevant nodes. The OTUs from the pilot plant obtained in this study are indicated as M07Axxx in boldface, while the OTUs from Joyo biological filtration plant are indicated as Jy04Axx. GenBank accession numbers are in parentheses.

On the other hand, no OTU closely related to Hyphomicrobium was obtained from the clone library of the pilot plant, while the OTU Jy04A47 was obtained from Joyo clone library. Hyphomicrobium spp. are methylotrophic, prosthecate bacteria, and some strains of Hyphomicrobium are known for the deposition of Fe and Mn oxides (Moore, 1981). In conclusion, it is suggested that Leptothrix-related bacteria were the dominant MnOB in the pilot plant, while Hyphomicrobium-related bacteria were the dominant $\mathrm{MnOB}$ in Joyo plant. The dominant population of Leptothrix-related bacterium in the BFR was 
also reported by Casiot et al. (2006). In contrast, Battaglia-Brunet et al. (2006) did not find the 16S rRNA gene clone of Leptothrix sp. S1.1 in the bacterial consortia of the BFR, although this strain was isolated from the sediments of the mine water they used. The relationship between the groundwater characteristics, especially As concentration and the compositions of $\mathrm{MnOB}$ are still unclear, so that further investigation is required.

\section{PCR detection of the genes encoding ammonia monooxygenase and arsenite oxidase}

It has been suggested that nitrifying bacteria would contribute to the biological removal of $\mathrm{Mn}$, because complete nitrification is required to take place for the biological removal of Mn when the raw groundwater contains ammonia (Mouchet 1992; Stembal et al., 2005). However, there was no OTU closely related to known AOB and nitrite oxidizing bacteria (NOB) in the 16S rRNA gene clone library from the pilot plant sample, although $\mathrm{NH}_{4}{ }^{+}$in raw groundwater was completely removed after the filtration. The presence of the AOB was confirmed by PCR-based detection of AOA- and AOB-amo $A$ genes, and PCR-amplified fragment of the AOB-amoA gene was detected (data not shown). Therefore, $\mathrm{NH}_{4}{ }^{+}$oxidation in the biological filtration system of the pilot plant was promoted by AOB. In Joyo plant, AOA-amoA but not AOB-amoA was detected (Thapa Chhetri et al., 2013). It has been known that AOA grow in a habitat with low $\mathrm{NH}_{4}{ }^{+}$concentration (Martens-Habbena et al., 2009). Moreover, it was also shown that the growth rates of the AOB increased with increasing $\mathrm{NH}_{4}^{+}$concentrations, while the growth rates of the AOA decreased slightly (French et al., 2012). The concentrations of $\mathrm{NH}_{4}{ }^{+}$in the raw groundwater of the pilot plant and Joyo plant were $0.76 \mathrm{mg} / \mathrm{L}$ and $0.11 \mathrm{mg} / \mathrm{L}$, respectively, and it is supposed that such a slight difference would affect the growth of AOA and AOB in the biological filtration reactor. The detection of NOB in the microbial consortia of the pilot plant has not succeeded yet, therefore further investigation would be needed.

Among the 16S rRNA gene clone library from the pilot plant sample, the OTU closely related to the arsenite-oxidizing bacterium Leptothrix sp. S1.1 was obtained as described above. Quéméneur et al. (2008) designed the oligonucleotide primer pair for PCR amplification of the gene encoding arsenite oxidase large subunit (aoxB), and cloned the aoxB gene from Leptothrix sp. S1.1. The detection of aoxB gene in the DNA solution extracted from the microbial floc sample of the pilot plant was examined using PCR. However, no obvious signal of the amplified aox $B$ gene fragment was observed (data not shown). It has been known that the distribution of $a o x B$ gene is widely spread in prokaryotes probably due to the horizontal gene transfer, and does not match with the phylogenetic relationship of 16S rRNA genes (Heinrich-Salmeron et al., 2011). The result suggested that the removal of As in the BFR of the pilot plant was conducted by the sorptive filtration of As with biogenic Fe and Mn oxides produced by the microbial consortia containing the bacteria closely related to Gallionella and Leptothrix. However, it is still unclear why aoxB was not detected in the pilot plant sample although the microbial consortia in the pilot plant came from the As-containing groundwater. In contrast, the studies for the simultaneous removal of As and $\mathrm{Fe}$ reported by Battaglia-Brunet et al. (2006) and Casiot et al. (2006) suggested that the removal of As was conducted by the combination of biological oxidation and physicochemical sorption. It should be noted that arsenite is oxidized to arsenate, and both of these soluble As oxyanions are adsorbed by the biogenic Fe and Mn oxides (Sahabi et al., 
2009). Thus, the principle of the biological filtration for the simultaneous removal of As, $\mathrm{Fe}$ and $\mathrm{Mn}$ is the production of $\mathrm{Fe}$ and $\mathrm{Mn}$ oxides by $\mathrm{FeOB}$ and MnOB. However, it is supposed that the presence (or inoculation) of arsenite-oxidizing bacteria in the biological filtration system would improve the efficiency of As removal. It is still difficult to reveal the mechanism of the simultaneous removal of As, Fe and $\mathrm{Mn}$ by the biological filtration system because of the difficulties of the pure cultivation of $\mathrm{FeOB}$ and $\mathrm{MnOB}$ in the microbial consortia. However, our analyses based on the nucleotide sequence information of the bacterial genes would help to understand the role of each $\mathrm{FeOB}, \mathrm{MnOB}$ and arsenite-oxidizing bacteria in the BFR. The primers for specific detection of the genes of Leptothrix, Gallionella, and Hyphomicrobium would be useful to survey the presence of these bacteria in the groundwater for construction and improvement of the biological filtration system. However, as described in this study, the primers already reported for the detection of $16 \mathrm{~S}$ rRNA genes of these bacteria showed unexpected amplification of the non-targeted clones in the clone libraries of the pilot plant and Joyo plant (unpublished data). Therefore, further investigation is required to develop the suitable primers for detection and quantification of $\mathrm{FeOB}$ and $\mathrm{MnOB}$ involved in the biological filtration system for the simultaneous removal of As, Fe and Mn from groundwater.

\section{CONCLUSIONS}

Bacterial diversity of the microbial consortia in the biological filtration pilot plant for the simultaneous removal of As, Fe and Mn was analyzed. PCR-DGGE analysis of bacterial 16S rRNA genes showed at least six dominant signals and many weak signals in the sample. Nucleotide sequence analysis of the 16S rRNA gene clone library showed 47 OTUs affiliated with four subclasses of the Proteobacteria, Actinobacteria, Acidobacteria, and Firmicutes. The phylogenetic analysis of the clone sequences indicated the presence of the bacteria closely related to Gallionella and Leptothrix, which are supposed to be involved in Fe and Mn oxidation in the pilot plant. In contrast, PCR-based survey of aoxB gene suggested that arsenite-oxidizing bacterium was not involved in the removal of As in the pilot plant. These results indicated that the biological filtration system of the pilot plant was conducted by the physicochemical sorption of As by the biogenic Fe and Mn oxides produced by the bacteria closely related to Gallionella and Leptothrix included in the microbial consortia of the reactor, unlike other studies for the simultaneous removal of As and $\mathrm{Fe}$ using the microbial consortia containing arsenite-oxidizing bacteria. Information of the compositions of microbial consortia in the biological filtration plants would be significant to improve the biological filtration systems for the removal of As from groundwater.

\section{ACKNOWLEDGEMENTS}

We are grateful to K. Tonokai of Groundwater Resource Development Center, Osaka Japan, and S. Tani of Toyo Rosuiki Co. Ltd., Kyoto, Japan, for the construction and operation of the pilot plant, as well as K. Nishida of Regional Environment System Co. Ltd., Kyoto, Japan. We also wish to thank K. Takada of Muko City Water Supply and Sewerage Department, Kyoto, Japan for the cooperation. This study was partially supported by JSPS Grant-in-Aid for Scientific Research (B) Number 18360253. 


\section{REFERENCES}

Battaglia-Brunet F., Itard Y., Garrido F., Delorme F., Crouzet C., Greffié C. and Joulian C. (2006) A simple biogeochemical process removing arsenic from a mine drainage water. Geomicrobiol. J., 23(3-4), 201-211.

Casiot C., Pedron V., Bruneel O., Duran R., Personné J. C., Grapin G., Drakidès C. and Elbaz-Poulichet F. (2006) A new bacterial strain mediating As oxidation in the Fe-rich biofilm naturally growing in a groundwater $\mathrm{Fe}$ treatment pilot unit. Chemosphere, 64(3), 492-496.

Čerňanský S., Urík M., Ševc J. and Khun M. (2007) Biosorption and biovolatilization of arsenic by heat-resistant fungi. Environ. Sci. Pollut. Res. Int., 14, Suppl. 1, 31-35.

Emerson D., Field E. K., Chertkov O., Davenport K. W., Goodwin L., Munk C., Nolan M. and Woyke T. (2013) Comparative genomics of freshwater Fe-oxidizing bacteria: Implications for physiology, ecology, and systematics. Front. Microbiol., 4, 254. (doi: 10.3389/fmicb.2013.00254)

Emerson D., Fleming E. J. and McBeth J. M. (2010) Iron-oxidizing bacteria: An environmental and genomic perspective. Annu. Rev. Microbiol., 64, 561-583.

Emerson D. and Moyer C. (1997) Isolation and characterization of novel iron-oxidizing bacteria that grow at circumneutral pH. Appl. Environ. Microbiol., 63(12), 4784-4792.

French E., Kozlowski J. A., Mukherjee M., Bullerjahn G. and Bollmann A. (2012) Ecophysiological characterization of ammonia-oxidizing archaea and bacteria from freshwater. Appl. Environ. Microbiol., 78(16), 5773-5780.

Fujikawa Y., Sugahara M., Hamasaki T., Yoneda D., Minami A., Sugimoto Y. and Iwasaki H. (2010) Biological filtration using iron bacteria for simultaneous removal of arsenic, iron, manganese and ammonia-Application to waterworks facilities in Japan and developing countries. Osaka Sangyo Univ. J. Hum. Environ. Stud., 9, 261-276. (http://journal.osaka-sandai.ac.jp/pdf/n9261-276.pdf, in Japanese) (accessed on March 6, 2014)

Ghiorse W. C. (1984) Biology of iron-and manganese-depositing bacteria. Annu. Rev. Microbiol., 38, 515-550.

Hassan K. M., Fukuhara T., Hai F. I., Bari Q. H. and Islam K. M. S. (2009) Development of a bio-physicochemical technique for arsenic removal from groundwater. Desalin., 249(1), 224-229.

Heinrich-Salmeron A., Cordi A., Brochier-Armanet C., Halter D., Pagnout C., Abbaszadeh-fard E., Montaut D., Seby F., Bertin P. N., Bauda P. and Arsène-Ploetze F. (2011) Unsuspected diversity of arsenite-oxidizing bacteria as revealed by widespread distribution of the aoxB gene in prokaryotes. Appl. Environ. Microbiol., 77(13), 4685-4692.

Hennebel T., De Gusseme B., Boon N. and Verstraete W. (2009) Biogenic metals in advanced water treatment. Trends Biotechnol., 27(2), 90-98.

Ike M., Miyazaki T., Yamamoto N., Sei K. and Soda S. (2008) Removal of arsenic from groundwater by arsenite-oxidizing bacteria. Water Sci. Technol., 58(5), 1095-1100.

Katsoyiannis I. A. and Zouboulis A. I. (2004) Application of biological processes for the removal of arsenic from groundwaters. Water Res., 38(1), 17-26.

Katsoyiannis I. A. and Zouboulis A. I. (2006) Use of iron- and manganese-oxidizing bacteria for the combined removal of iron, manganese and arsenic from contaminated groundwater. Water Qual. Res. J. Can., 41(2), 117-129.

Lane D. J., Pace B., Olsen G. J., Stahl D. A., Sogin M. L. and Pace N. R. (1985) Rapid 
determination of $16 \mathrm{~S}$ ribosomal RNA sequences for phylogenetic analyses. Proc. Natl. Acad. Sci. U.S.A., 82(20), 6955-6959.

Marchesi J. R., Sato T., Weightman A. J., Martin T. A., Fry J. C., Hiom S. J. and Wade W. G. (1998) Design and evaluation of useful bacterium-specific PCR primers that amplify genes coding for bacterial 16S rRNA. Appl. Environ. Microbiol., 64(2), 795-799.

Martens-Habbena W., Berube P. M., Urakawa H., de la Torre J. R. and Stahl D. A. (2009) Ammonia oxidation kinetics determine niche separation of nitrifying archaea and bacteria. Nature, 461(7266), 976-979.

Mohan D. and Pittman Jr. C. U. (2007) Arsenic removal from water/wastewater using adsorbents - A critical review. J. Hazard. Mater., 142(1-2), 1-53.

Moore R. L. (1981) The biology of Hyphomicrobium and other prosthecate, budding bacteria. Annu. Rev. Microbiol., 35, 567-594.

Mouchet P. (1992) From conventional to biological removal of iron and manganese in France. J. Am. Water Works Assn., 84(4), 158-167.

Nakatsu C. H., Hristova K., Hanada S., Meng X. Y., Hanson J. R., Scow K. M. and Kamagata Y. (2006) Methylibium petroleiphilum gen. nov., sp. nov., a novel methyl tert-butyl ether-degrading methylotroph of the Betaproteobacteria. Int. J. Syst. Evol. Microbiol., 56(5), 983-989.

Pacini V. A., Ingallinella A. M. and Sanguinetti G. (2005) Removal of iron and manganese using biological roughing up flow filtration technology. Water Res., 39(18), 4463-4475.

Pokhrel D. and Viraraghavan T. (2009) Biological filtration for removal of arsenic from drinking water. J. Environ. Manage., 90(5), 1956-1961.

Quéméneur M., Heinrich-Salmeron A., Muller D., Lièvremont D., Jauzein M., Bertin P. N., Garrido F. and Joulian C. (2008) Diversity surveys and evolutionary relationships of aoxB genes in aerobic arsenite-oxidizing bacteria. Appl. Environ. Microbiol., 74(14), 4567-4573.

Rahman M. A. and Hasegawa H. (2011) Aquatic arsenic: Phytoremediation using floating macrophytes. Chemosphere, 83(5), 633-646.

Sahabi D. M., Takeda M., Suzuki I. and Koizumi J. (2009) Adsorption and abiotic oxidation of arsenic by aged biofilter media: Equilibrium and kinetics. J. Hazard. Mater., 168(2-3), 1310-1318.

Sari A. and Tuzen M. (2009) Biosorption of As(III) and As(V) from aqueous solution by macrofungus (Inonotus hispidus) biomass: Equilibrium and kinetic studies. $J$. Hazard. Mater., 164(2-3), 1372-1378.

Siering P. L. and Ghiorse W. C. (1997) Development and application of 16S rRNA-targeted probes for detection of iron- and manganese-oxidizing sheathed bacteria in environmental samples. Appl. Environ. Microbiol., 63(2), 644-651.

Smith J. P. and Lewis G. D. (2008) Unusual bacterially mediated manganese-based structures within biofilms from urban streams. The 12 th International Symposium on Microbial Ecology (ISME12), Aug. 17-22, Cairns, Australia, 0183.

Solorzano L. (1969) Determination of ammonia in natural waters by the phenol hypochlorite method. Limnol. Oceanogr., 14(5) 799-801.

Štembal T., Markić M., Ribičić N., Briški F. and Sipos L. (2005) Removal of ammonia, iron and manganese from groundwaters of northern Croatia-pilot plant studies. Process Biochem., 40(1), 327-335.

Stoecker K., Bendinger B., Schöning B., Nielsen P. H., Nielsen J. L., Baranyi C., 
Toenshoff E. R., Daims H. and Wagner M. (2006) Cohn's Crenothrix is a filamentous methane oxidizer with an unusual methane mono-oxygenase. Proc. Natl. Acad. Sci. U.S.A., 103(7), 2363-2367.

Sugahara M., Fujikawa Y., Hamasaki T., Minami A., Yoneda D., Tonokai K., Tani S., and Nishida K. (2008) Arsenic removal from groundwater using indigenous iron and manganese oxidizing bacteria. Annu. Report FY 2007, The Core University Program between Japan Society for the Promotion of Science (JSPS) and Vietnamese Academy of Science and Technology (VAST), 403-407. (http://ir.library.osaka-u.ac.jp/dspace/bitstream/11094/13060/1/arfyjsps2007_403.pd f) (accessed on March 6, 2014)

Thapa Chhetri R., Suzuki I., Takezaki J., Tabusa H., Takeda M. and Koizumi J. (2013) Bacterial diversity in biological filtration plant for the removal of iron and manganese from groundwater. J. Water Environ. Technol., 11(1), 33-47.

van Veen W. L., Mulder E. G. and Deinema M. H. (1978) The Sphaerotilus-Leptothrix group of bacteria. Microbiol. Rev., 42(2), 329-356.

WHO (1996) Guidelines for drinking-water quality. Health criteria and other supporting information, 2nd ed. World Health Organization, Geneva, Switzerland, pp.940-949. 